DOI: $10.2478 / \mathrm{v} 10014-011-0001-0$

COBISS Code 1.01

Agrovoc descriptors: meloidogyne,nematoda,pest control,pesticides,plant extracts,pest resistance,tomatoes,lycopersicon esculentum, greenhouses

Agris category code: $\mathrm{H} 10$

\title{
The effect of some insecticides, natural compounds and tomato cv. Venezia with Mi gene on the nematode Meloidogyne ethiopica (Nematoda) reproduction
}

\author{
Polona STRAJNAR ${ }^{1}$ and Saša ŠIRCA ${ }^{2}$
}

Received: October 6, 2010; accepted: December 27, 2010.

Delo je prispelo: 6. oktobra 2010; sprejeto: 27. decembra 2010.

\begin{abstract}
Root-knot nematode (RKN) Meloidogyne ethiopica is quite unknown tropical plant parasitic species found in Slovenia and Europe in 2003 for the first time. The species is able to parasitize several economically important agricultural crops and therefore is very difficult to control. In our research, several approaches which can be used for M. ethiopica control were tested in pot experiment. The effects of some insecticides which are often used in the production in greenhouses, natural compounds as aqueous extract of Tagetes erecta, and the commercial natural product Azadirachtin (NeemAzal-T/S) extracted from the seeds of Indian Neem tree (Azadirachta indica) on the $M$. ethiopica reproduction were assessed. Test plants treatments with natural compounds reduced nematode multiplication by nearly $3-6$ times compared to control while foliar application of Thiacloprid as well as Imidacloprid had no effect on nematode reproduction. The treatment with Volaton G granulates (Phoxim) for ground application resulted in no nematode multiplication. Additionally, M. ethiopica reproduction ability on the tomato cultivar "Venezia" which have a Mi gene for resistance to $M$. incognita was tested.
\end{abstract}

Key words: root knot nematode, M. ethiopica, control, pesticides, plant extracts, resistant tomato
IZVLEČEK

\author{
VPLIV NEKATERIH INSEKTICIDOV, NARAVNIH \\ RASTLINSKIH IZVLEČKOV IN PARADIŽNIKA \\ SORTE VENEZIA Z Mi GENOM NA \\ RAZMNOŽEVANJE OGORČIC VRSTE Meloidogyne \\ ethiopica (NEMATODA)
}

Meloidogyne ethiopica spada med ogorčice koreninskih šišk in je dokaj neznana, tropska rastlinsko parazitska vrsta, ki je bila prvič ugotovljena v Sloveniji in Evropi leta 2003. Vrsta lahko zajeda številne gospodarsko pomembne kmetijske rastline in jo zaradi tega zelo težko zatiramo. $\mathrm{V}$ naši raziskavi smo $\mathrm{v}$ lončnem poskusu ovrednotili različne prijeme, ki bi bili lahko uporabni za njeno zatiranje. Preučevali smo vpliv različnih substanc na reprodukcijo ogorčice $M$. ethiopica. Preučili smo vpliv nekaterih insekticidov, ki se jih pogosto uporablja $\mathrm{v}$ proizvodnji v rastlinjakih, ter nekaterih rastlinskih izvlečkov, kot sta vodni ekstrakt iz vrste Tagetes erecta in ekstrakt semen indijskega drevesa Azadirachta indica, ki vsebuje azadirahtin in je dostopen kot komercialni pripravek NeemAzal-T/S. Zalivanje testnih rastlin $\mathrm{z}$ rastlinskimi izvlečki je zmanjšalo reprodukcijo ogorčic za 3 do 6 krat v primerjavi s kontrolami, medtem ko foliarno tretiranje $\mathrm{s}$ tiaklopridom kot tudi $\mathrm{z}$ imidaklopridom na reprodukcijo ni imelo učinka. Prav nasprotno je učinkoval granulat za talno tretiranje Volaton $G$ (foksim), kjer reprodukcije ogorčic nismo opazili. Preučili smo tudi reprodukcijski potencial ogorčice $M$. ethiopica pri paradižniku sorte "Venezia", ki vsebuje Mi gen za odpornost na ogorčice vrste $M$. incognita.

Ključne besede: ogorčice koreninskih šišk, $M$. ethiopica, zatiranje, pesticidi, rastlinski izvlečki, odporen paradižnik

\footnotetext{
${ }^{1}$ Young researcher, B.Sc., Agricultural institute of Slovenia, Hacquetova ulica 17, SI- 1000 Ljubljana, email: polona.strajnar@kis.si

${ }^{2}$ Ph.D, Agricultural institute of Slovenia, Hacquetova ulica 17, SI- 1000 Ljubljana
} 


\section{INTRODUCTION}

Root-knot nematodes (RKNs) of the genus Meloidogyne belong to the economically most important group of plant parasitic nematodes. They are obligate parasites that attack numerous higher plant species including monocotyledons, dicotyledons, herbaceous and woody plants (Eisenback and Hirschmann, 1991). RKN causes development of galls on the plant host roots and therefore water and nutrient intake are limited. Plants infested with RKNs do not show specific above ground symptoms but different symptoms like stunting, wilting and sometimes early flower and fruit drop can be observed.

Two RKN species, M. chitwoodi and M. fallax, are quarantine pests for EU and EPPO region but several RKN species are also important for vegetable production causing substantial yield losses worldwide. Four species of RKN have been detected in Slovenia so far: $M$. arenaria, $M$. incognita, M. hapla and $M$. ethiopica (Širca and Urek, 2004; Širca et al., 2004a; Širca et al., 2004b). M. ethiopica was established in 2003 in the greenhouse situated in the Primorska region as the first finding of this species in Slovenia and Europe (Širca et al., 2004b). RKNs are very difficult to control because of their polyphagous nature of parasitism and more limited approaches to their chemical control recently available. Several RKN species are able to parasitize and successfully multiply on monocotyledonous plants as well as on woody and herbaceous dicotyledonous plants. Meloidogyne ethiopica was shown to be such a case with the wide host range on the following plants: broad bean (Vicia $f a b a)$, black wattle, cabbage, cowpea, pepper, potato, pumpkin, tobacco, tomato (Whitehead, 1969). Carneiro et al. $(2004,2007)$ found M. ethiopica on grapevine, kiwi fruit and watermelon. Besides, barley, bean, beet, broccoli, carrot, cauliflower, celery, chicory, cucumber, curled dock, eggplant, endive, florence fennel, kale, kohlrabi, lettuce, melon, onion, pea, radish, spinach, strawberry, sunflower and sweet corn were also shown to be the host plant species (Strajnar et al., 2009).

Meloidogyne ethiopica is quite unknown tropical RKN species found in Europe for the first time and, because of that, we decided to test several approaches which can be used for their control. In this research we studied the effects of some insecticides which are frequently used in greenhouse production, natural compounds as aqueous extract of Tagetes erecta, and the commercial natural product of $1 \%$ Azadirachtin (NeemAzal-T/S) extracted from the seeds of Indian Neem tree (Azadirachta indica) on the $M$. ethiopica reproduction. Additionally, $M$. ethiopica reproduction ability on the tomato cultivar "Venezia" which have a Mi gene for resistance to $M$. incognita was tested.

\section{MATERIALS AND METHODS}

The experiment was carried out in the glasshouse on the tomato plants Lycopersicon lycopersicum cv. Volovsko srce which is susceptible to RKN M. ethiopica (Strajnar et al., 2009). Tomato variety "Venezia" was obtained from Seminis. The experiment was randomized in blocks with five replications of each treatment including untreated pots as a control. Three chemical treatments and two treatments with natural compounds were tested (Table 1).

The tomato plants were planted individually in $16 \mathrm{~cm}$ diameter pots filled with $1960 \mathrm{~g}$ of fine sterilized sand (particle size: $0.25-1.0 \mathrm{~mm}$ ). The daily growing temperatures ranged from 20 to $30^{\circ} \mathrm{C}$. Watering was obtained for manual keeping $15 \%$ of moisture of the dry sand weight (Kutywayo and Been, 2006). Nutrients for hydroponic grow (Flora series) were used. Nutrient concentration depended on the stage of plant development.

\section{Nematode inocolum}

The cultures of $M$. ethiopica were maintained on the bean Phaseolus vulgaris cv. Meraviglia di Venezia nano planted in sterilized sand (particle size: $0.25-1.0 \mathrm{~mm}$ ) and kept in a glasshouse at 20 to $27^{\circ} \mathrm{C}$. After forty-five days, the cultures were used for inoculum preparation. Inoculum of nematode eggs was prepared by shaking chopped galled bean roots in
$1 \%$ sodium hypochlorite $(\mathrm{NaClO})$ for 4 min to dissolve the gelatinous matrix surrounding root-knot nematode eggs (Hussey and Barker, 1973). The suspension of eggs was washed through 850,250 and $32 \mu \mathrm{m}$ banked sieves. The eggs on the lower sieve were washed with tap water to remove $\mathrm{NaClO}$ (Ehwaeti et al., 1998) and rinsed from the sieve in 40 $\mathrm{ml}$ of water into $50 \mathrm{ml}$ polycarbonate centrifuge tubes. The tubes were centrifuged at $1500 \mathrm{rpm}$ for $5 \mathrm{~min}$. The pellets which contained the eggs and plant tissues were re-suspended in $40 \mathrm{ml}$ of sucrose solution (454 g sucrose per 1 liter of tap water) and centrifuged at $1000 \mathrm{rpm}$ for $1 \mathrm{~min}$ (McClure et al., 1973). The supernatants were poured through $32 \mu \mathrm{m}$ banked sieve and washed with $200 \mathrm{ml}$ tap water. The eggs were rinsed from the sieve and counted. Forty-five days old tomato plants were inoculated with the aqueous solution of 5000 eggs of $M$. ethiopica per plant. 
The effect of some insecticides, natural compounds and tomato cv. Venezia with Mi gene on the nematode ...

Chemical and natural compound treatments

Table 1: Application times and applied doses used for chemical and natural compound treatment.

\begin{tabular}{lll}
\hline Treatments & Application times & Dose \\
\hline Calypso SC 480 & Twice: two WAI and four WAI & $3 \mathrm{ml} / 101 \mathrm{H}_{2} \mathrm{O}(0.03 \%)$ \\
Confidor SL 200 & Twice: two WAI and four WAI & $6 \mathrm{ml} / 101 \mathrm{H}_{2} \mathrm{O}(0.06 \%)$ \\
Aqueous extract of Tagetes erecta & Twice: one DBI and two WAI & $100 \mathrm{ml} / 11 \mathrm{H}_{2} \mathrm{O}(10 \%)$ \\
NeemAzal-T/S ${ }^{\text {a }}$ & Twice: one DBI and two WAI & $30 \mathrm{ml} / 101 \mathrm{H}_{2} \mathrm{O}(0.3 \%)$ \\
NeemAzal-T/S & Twice: one DBI and two WAI & $100 \mathrm{ml} / 101 \mathrm{H}_{2} \mathrm{O}(1 \%)$ \\
Volaton G 5\% & Once: one DBI & $1 \mathrm{~kg} / 100 \mathrm{~m}^{2}$ \\
\hline
\end{tabular}

WAI Week after inoculation

${ }^{\mathrm{DBI}}$ Day before inoculation

${ }^{\text {a }}$ NeemAzal-T/S was applied at the dose of $0.3 \%$.

${ }^{\mathrm{b}}$ NeemAzal-T/S was applied at the dose of $1 \%$.

Thiacloprid - Calypso SC 480 (Bayer CropScience) and Imidacloprid - Confidor SL 200 (Bayer CropScience) were used in the dosage according to manufacturer instructions for insect control applications. The applications of systemic insecticides on the leaves were performed twice. The first application was carried out two weeks after inoculation and the second four weeks after inoculation. Phoxim - Volaton G 5\% (Pinus TKI d.d., Slovenia) granules were applied under the surface of the sand according to manufacturer's instruction one day before inoculation.

Aqueous extract of Tagetes erecta was made from the three month old plants. $200 \mathrm{~g}$ of the whole plant material (roots, steam, leaves and blossoms) was mashed by a blender and soaked in $100 \mathrm{ml}$ of tap water across the night. The aqueous extract was filtered through the gauze and stored at $-20^{\circ} \mathrm{C}$ before use. $50 \mathrm{ml}$ of $10 \% \mathrm{~T}$. erecta aqueous extract was applied per plant twice, one day before inoculation and 14 days after inoculation. Azadirachtin - NeemAzal-T/S
(Trifolio-M GmbH, Lachnau, Germany) was applied in $0.3 \%$ and $1 \%$ concentrations to the sand around the plant. The first application was done one day before inoculation and the second two weeks after inoculation.

\section{Analysis of nematode reproduction extent}

The experiment was terminated forty-five days after inoculation when tomato roots were removed and nematode reproduction was assessed. Males and second stage juveniles were isolated from the sand by a decanting method (Hržič, 1973) followed by Berman's funnel extraction. Nematode eggs were isolated as previously described. Reproduction factor $(\mathrm{R})$ was calculated as final nematode population divided by initial nematode population $(\mathrm{R}=\mathrm{Rf} / \mathrm{Ri})$. The data were statistically analyzed by analysis of variance (ANOVA) and significant differences in means ranked by least significant difference multiple range test (LSD) (Statgraphics versions $\mathrm{XV})$.

\section{RESULTS}

Application of systemic insecticides Calypso SC 480 and Confidor SL 200 did not significantly differ from the control on nematode multiplication (Fig. 1). The reproduction factor ranged from 25.1 to 28.2 (Tab. 2). The treatment with aqueous extract of Tagetes erecta was significantly different from all chemical treatments, NeemAzal-T/S treatments and from tomato cv. Venezia with Mi gene (Fig.1). The Tagetes aqueous extract reduced the nematode population by nearly 3 times (2.6) compared to untreated control and the reproduction factor was 10.4. Treatments with Azadirachtin had a significant effect on the reproduction of nematodes compared to untreated plants (Fig. 1, Fig. 2). The reproduction factors were 4.3 and 6.2 for higher $(1 \%)$ and lower $(0.3 \%)$ concentration treatments, respectively. The analyses of Azadirachtin treatments also revealed deformed eggs of M. ethiopica (Fig. 3A) which were not viable and therefore not included in the final population sum. 


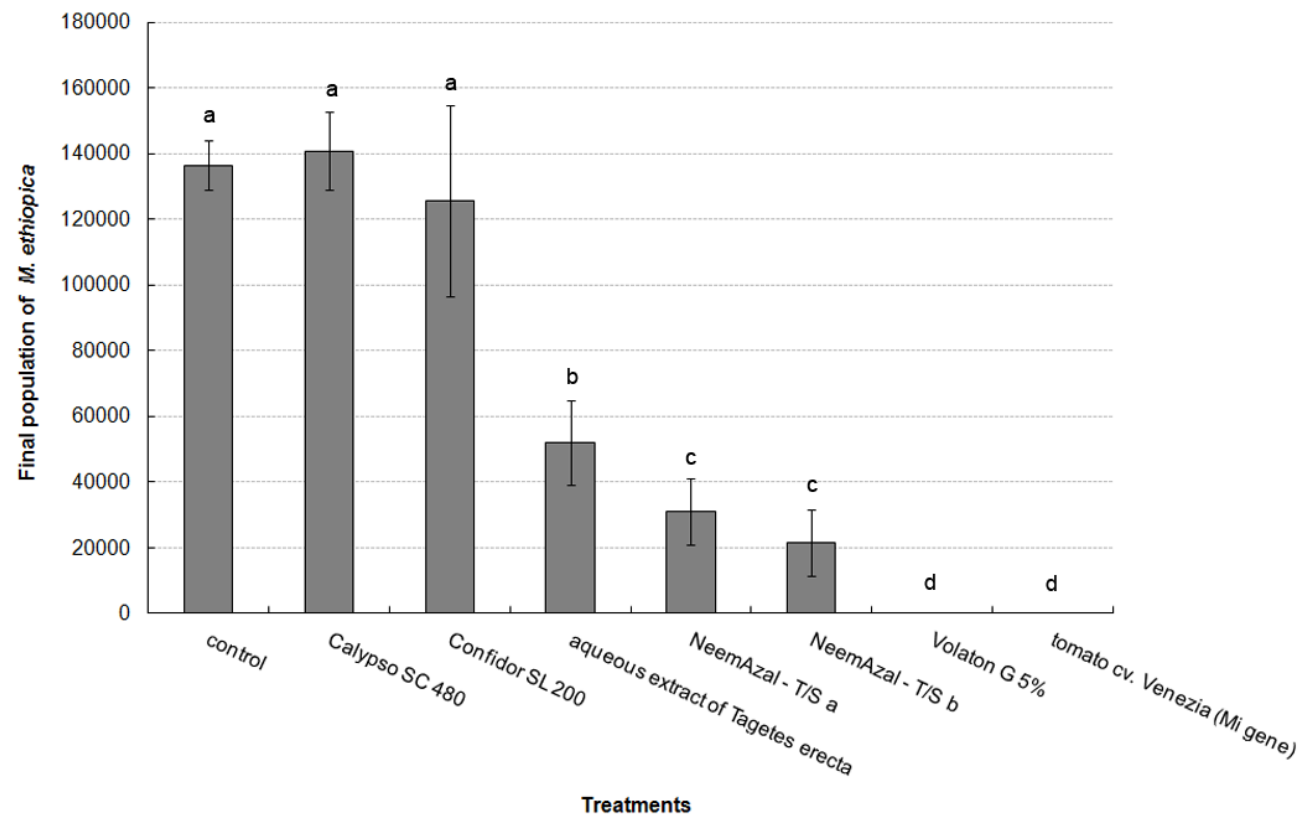

Figure 1: The effect of different chemical and natural compound treatments and tomato cv. Venezia on the final population of $M$. ethiopica. The data are presented as means and standard deviation of five replicates. a, b, $\mathrm{c}$ and $\mathrm{d}$ represent homogenous groups (not significantly different) at $\mathrm{P} \leq 0.05$ by LSD multiple range test. NeemAzal-T/S a: application at $0.3 \%$ dose. NeemAzal-T/S b: application at $1 \%$ dose.
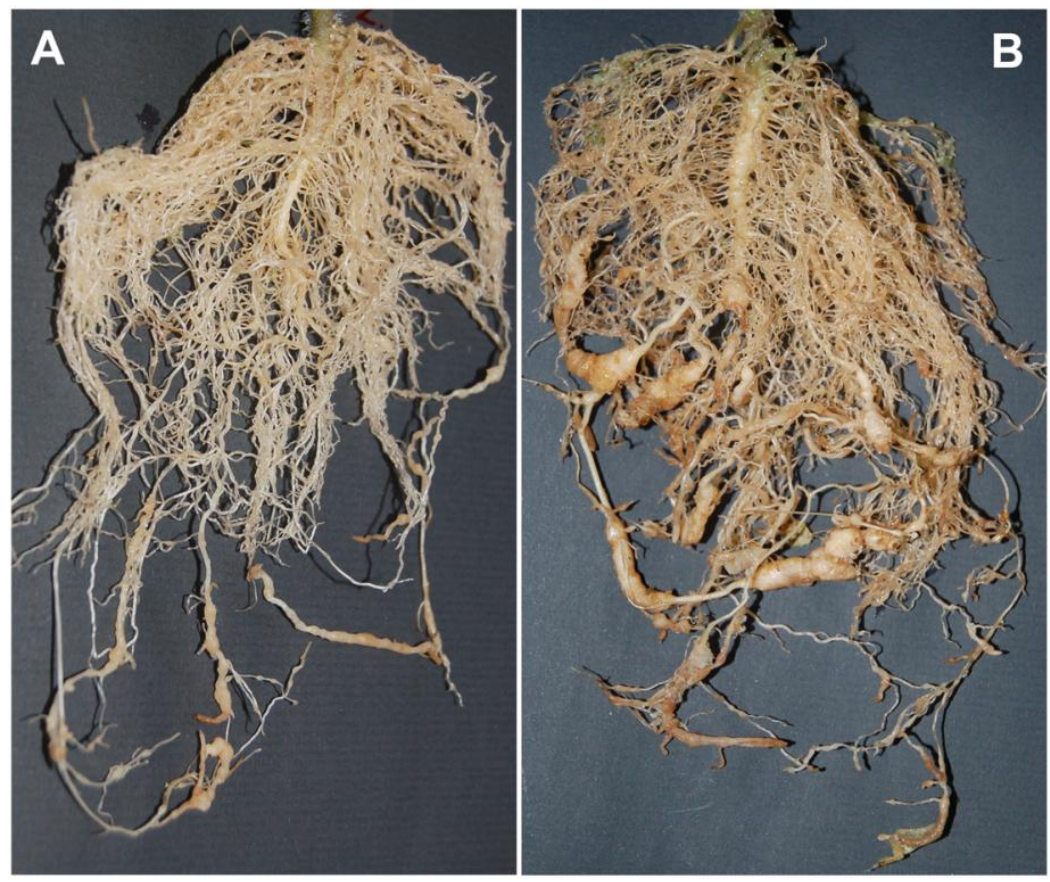

Figure 2: The reduction of nematode infection and reproduction on tomato treated with $1 \%$ NeemAzal-T/S (A) compared to an untreated control plant (B). 


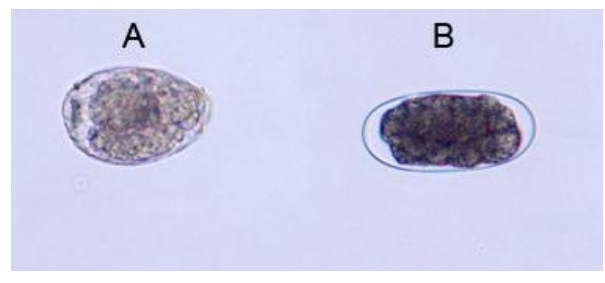

Figure 3: Deformed eggs of $M$. ethiopica were observed after Azadirachtin treatments (A); Healthy egg of $M$. ethiopica from an untreated control tomato plant (B).

No nematode reproduction was observed on the roots of plants where Volaton G 5\% was used and on the roots of tomato cv. Venezia. The reproduction factors of those two variants significantly differed from all the other variants including control.

Table 2: Reproduction factors of M. ethiopica for different chemical and natural compound treatments and tomato cv. Venezia.

\begin{tabular}{ll}
\hline Treatments & Reproduction factors \\
\hline Control & 27.3 \\
Calypso SC 480 & 28.2 \\
Confidor SL 200 & 25.1 \\
Aqueous extract of Tagetes erecta & 10.4 \\
NeemAzal-T/S 0.3\% & 6.2 \\
NeemAzal-T/S 1\% & 4.3 \\
Volaton G 5\% & 0.0 \\
Tomato cv. Venezia (Mi gene) & 0.0 \\
\hline
\end{tabular}

\section{DISCUSSION}

Root knot nematodes are important plant pests with a worldwide distribution. In the agricultural production they cause great yield losses when they over reproduce therefore it is important to develop useful control methods. RKN M. ethiopica is difficult to control because of their wide host range attacking most of the vegetable grown in the greenhouses and high rates of reproduction. The nematode can parasitize monocotyledons as well as dicotyledons which limits the use of crop rotation as a strategy to control the nematode reproduction. Besides, chemical control approaches are becoming less available recently. On the contrary, natural compounds are more acceptable for the environment and they are becoming more and more popular. However, their usefulness and efficiency for pest control needs to be assessed.
The aim of our experiment was to establish if any insecticides or natural compound influence the $M$. ethiopica reproduction, which is new species for Slovenian environment. The effects of some insecticides which are frequently used in greenhouse production, natural compounds as extract of Tagetes erecta and natural product of $1 \%$ Azadirachtin (NeemAzal-T/S) extracted from the seeds of Indian Neem tree (Azadirachta indica) as well as tomato cv. Venezia with Mi resistance gene on M. ethiopica reproduction were tested. The data showed that the insecticide Volaton G 5\% and tomato with Mi gene prevented the reproduction of the nematode. Our results showed that Mi gene has significant effect on $M$. ethiopica reproduction suggesting that production of resistant cultivars with $\mathrm{Mi}$ gene could be successful non-chemical measure for controlling the nematode. Foliar application of 
Thiacloprid or Imidacloprid had no effect on nematode reproduction as both treatments showed no significant difference from the control plants.

Natural compounds treatments reduced nematode reproduction by 2.6, 4.4 and 6.3 times for Tagetes extract, $0.3 \%$ NeemAzal-T/S and $1 \%$ NeemAzal-T/S, respectively, compared to untreated controls. The analyses of final nematode populations after Azadirachtin treatments revealed deformed non-viable eggs of $M$. ethiopica. Such observations are reported for the first time on nematodes. However, similar observations were reported for common cockcafter Melolontha melolontha L. where $80-90 \%$ of females which were fed with Azadirachtin treated oak leaves were not able to produce viable eggs (Malinowski et al., 2003). The treatment with the Tagetes aqueous extract was not so efficient as Azadirachtin treatments but more concentrated extract could give better results which we plan to examine in the future.

\section{ACKNOWLEDGEMENTS}

The research was financially supported by the grants (L4-1021) of the Slovenian Research Agency and the
Ministry of Agriculture, Forestry and Food of the Republic of Slovenia.

\section{REFERENCES}

Carneiro R.M.D.G., Randing O., Almeida M.R.A., Gomes A.C.M.M. 2004. Additional information on Meloidogyne ethiopica Whitehead, 1968 (Tylenchida: Meloidogynidae), a root-knot nematode parasitising kiwi fruit and grape-vine from Brazil and Chile, Nematology 6: $109-123$

Carneiro R.M.D.G., Almeida M.R.A., Cofcewicz E.T., Magunacelaya J.C., Aballay E. 2007. Meloidogyne ethiopica, a major root-knot nematode parasitising Vitis vinifera and other crops in Chile, Nematology 9: 635641.

Eisenback J.D., Hirschmann H.T. 1991. Root-Knot nematodes: Meloidogyne species and races, in: Manual of agricultural nematology (Nickle, W. R). Marcel Dekker, Inc. New York, Basel, Hong Kong. pp. 191-274.

Ehwaeti M.E., Phillips M.S., Trudgill D.L. 1998. The viability of Meloidogyne incognita eggs released from egg masses of different ages using different concentrations of sodium hypochlorite, Nematologica 44: 207-217.

Hržič A. 1973. [Extraction of nematodes from soil with whirling motion], Zaštita bilja 122: 53-60.

Hussey R.S., Barker K.R. 1973. A comparison of methods of collecting inocula of Meloidogyne spp. including a new technique, Plant Disease Reporter 57: 1025-1028.

Kutywayo V., Been T.H. 2006. Host status of six major weeds to Meloidogyne chitwoodi and Pratylenchus penetrans, including a preliminary field survey concerning other weeds, Nematology 8: 647-657.

Malinowski H., Worwta D., Stocki J. 2003. Experiments with Azadirachtin to reduce common cockchafer (Mellolontha melolontha L.) and some leaf-eating insects from the order Lepidoptera, www/deu/intland/Files/WS8\%20oeffentliches $\% 20$ graen $\% 204$ pdf.

McClure M.A., Kruk T.H., Misaghi I. 1973. A method for obtaining quantities of clean Meloidogyne eggs, J. Nematol. 5: 230.
Strajnar P., Širca S., Geric Stare B., Urek G. 2009. Characterization of Root Knot Nematode Meloidogyne ethiopica Whitehead, 1968 from Slovenia, Russian Journal of Nematology 17: 135-142.

Širca S., Urek G. 2004. Dissemination of the root-knot nematodes, Meloidogyne spp. in Slovenia, Razprave Slovenska akademija znanosti in umetnosti 45: 161-170.

Širca S., Urek G., Karssen G. 2004a. The incidence of the root-knot nematode Meloidogyne incognita and Meloidogyne hapla in Slovenia, Acta agriculturae slovenica 83: 15-22.

Širca S., Urek G., Karssen G. 2004b. First report of the RootKnot Nematode Meloidogyne ethiopica on Tomato in Slovenia, Plant disease 88: 680.

Whitehead A.G. 1969. The distribution of root-knot nematodes (Meloidogyne spp.) in tropical Africa, Nematologica 15: 315-333. 